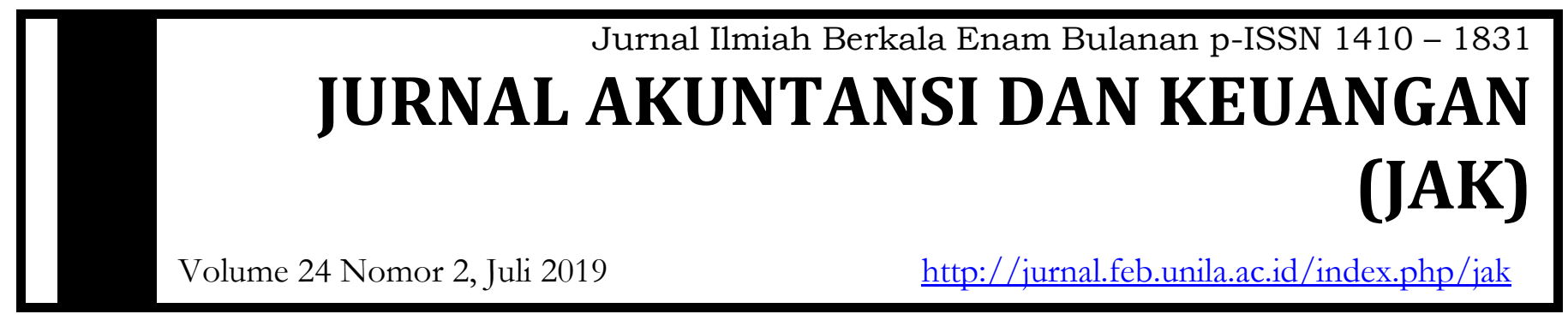

\title{
PENGARUH FAKTOR MIKROEKONOMI DAN MAKROEKONOMI TERHADAP KEBIJAKAN HUTANG PERUSAHAAN
}

\author{
Tika Larasati Harjito Putri' ${ }^{1}$, Ratna Septiyanti², Widya Rizki Eka Putri ${ }^{3}$ \\ ${ }^{1}$ Fakultas Ekonomi dan Bisnis Universitas Lampung \\ 2Fakultas Ekonomi dan Bisnis Universitas Lampung \\ ${ }^{3}$ Fakultas Ekonomi dan Bisnis Universitas Lampung
}

\section{Informasi Naskah}

Update Naskah:

Dikumpulkan: 19 Des 2019;

Diterima: 22 January 2020;

Terbit/Dicetak: 30 January 2020.

\section{Keywords:}

microeconomics factors, macroeconomics factors, and debt policy.

\section{$\underline{\text { Abstract }}$}

The purposed of research is to get empirical evidence about the effect of microeconomics and macroeconomics factors to debt policy. This research used the Financial Companies which is listed in Indonesia stock exchange started the year 2014-2018 with total 32 Companies. Samples are selected based on purposive sampling method with the purpose to get sample according to research aim. Sample consists of 160 observations. The analytical technique was multiple regressions. The research results show that microeconomics factors which are proxied by corporate growth, corporate size, and blockholder ownership has significant effect to debt policy. However, macroeconomics factors which are proxied by political stability and inflation rates has no significant effect to debt policy. 


\section{A. PENDAHULUAN}

Setiap perusahaan membutuhkan dana untuk memenuhi kebutuhan modalnya, sehingga dapat menjalankan kegiatan operasi dan mengembangkan usahanya. Perusahaan dapat memperoleh dana melalui sumber pendanaan internal maupun eksternal. Laba ditahan sebagai sumber dana internal diperoleh dari kegiatan operasi perusahaan. Sumber dana eksternal dapat diperoleh melalui penerbitan saham baru atau pinjaman dana berupa hutang (Soraya dan Permanasari, 2017).

Menurut Hanafi (2016), peningkatan penggunaan hutang jika tidak diiringi dengan kemampuan perusahaan dalam memelihara hutang dengan baik dapat mengakibatkan kebangkrutan. Semakin tinggi hutang, semakin besar bunga yang harus dibayar. Berdasarkan Gambar 1 jumlah perusahaan Indonesia yang dimohonkan pailit terus mengalami peningkatan selama periode 2014-2017.

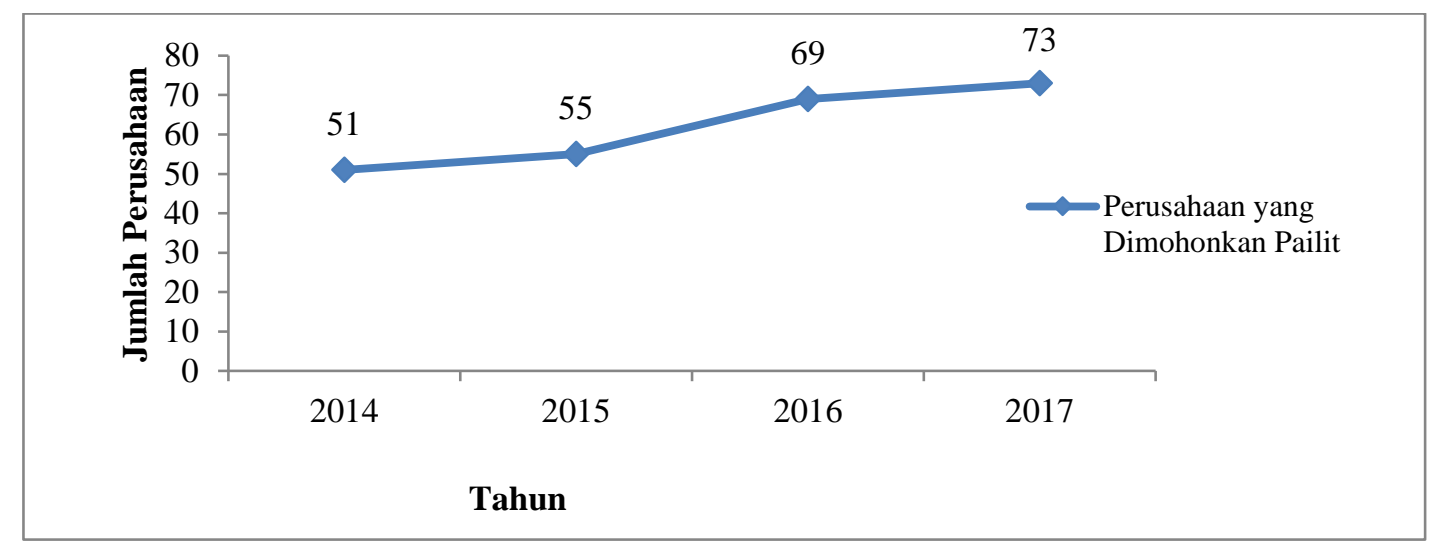

Gambar 1 Jumlah perusahaan Indonesia yang dimohonkan pailit selama 2014-2017.

Penting bagi pengguna hutang untuk melihat dampak dan korelasi hutang dengan faktor kondisi mikro dan makro ekonomi untuk memutuskan kebijakan utang layak atau tidak untuk dilakukan (Fahmi, 2014). Faktor mikroekonomi dalam penelitian ini adalah pertumbuhan perusahaan, ukuran perusahaan, dan blockholder ownership. Faktor makroekonomi dalam penelitian ini adalah kestabilan politik dan tingkat inflasi. Pertumbuhan perusahaan merupakan penambahan kekayaan perusahaan dibandingkan dengan tahun sebelumnya yang tercermin dari nilai pendapatannya. Peningkatan pendapatan tersebut membutuhkan sumber dana yang dapat berasal dari internal maupun eksternal perusahaan. (Sanusi dan Nazar, 2014).

Ukuran perusahaan digambarkan dengan total aset yang dimiliki perusahaan dan diharapkan untuk memperoleh keuntungan dimasa yang akan datang, selain itu aset perusahaan digunakan sebagai jaminan atas hutang yang dilakukan oleh perusahaan. Semakin besar ukuran perusahaan maka pengeluaran perusahaan juga semakin besar (Firmansyah et al., 2016). Menurut Thomsen et al. dalam Dictio (2019), blockholder ownership adalah ukuran kepemilikan saham kepemilikan saham yang jumlahnya lebih dari 5\% dari jumlah saham yang beredar. Menurut Darsono (2001), di Amerika Serikat kepemilikan 5\% dari jumlah saham yang beredar sudah signifikan dalam RUPS, namun di Indonesia masih banyak investor yang menguasai lebih dari 50\% dari jumlah saham beredar. Semakin besar penguasaan saham oleh sekelompok kecil perusahaan atau blockholder maka makin besar keberanian mereka mengambil pinjaman atau memperbesar kebijakan hutang (Maryasih dan Gemala, 2014).

Kestabilan politik adalah standar untuk mengukur persepsi tentang kemungkinan ketidakstabilan politik dan atau kekerasan bermotif politik, termasuk terorisme (Razak dan Suhadak, 2019). Ketidakstabilan politik akan mengarah pada kebijakan makroekonomi jangka pendek yang tidak optimal atau meningkatkan kebijakan yang tidak pasti, sehingga menghasilkan lingkungan politik-ekonomi yang tidak pasti, meningkatkan risiko bisnis, dan mengurangi investasi (Aisen dan Veiga, 2011).

Menurut Bank Indonesia, inflasi adalah kenaikan harga secara umum dan terus menerus dalam jangka waktu tertentu. Menurut Staikouras dan Wood (2003) dalam Kosmidou (2008), inflasi memiliki efek langsung terhadap beban-beban perusahaan. Beban operasional yang meningkat dapat menurunkan laba 
perusahaan, sehingga perusahaan cenderung menggunakan hutang (Firmansyah et al., 2016). Pemilihan sampel pada perusahaan sektor keuangan dalam penelitian ini dikarenakan berdasarkan data Bank Indonesia, yaitu Surat Utang Luar Negeri Indonesia (SULNI), perusahaan sektor keuangan memiliki jumlah hutang terbesar dibandingkan sektor ekonomi lainnya selama tahun 2014-2018.

Penelitian-penelitian tentang pengaruh faktor mikroekonomi dan makroekonomi terhadap kebijakan hutang masih memberikan hasil yang belum konsisten. Penelusuran riset-riset sebelumnya yang mengkaji tentang pengaruh pertumbuhan perusahaan terhadap kebijakan hutang, masih menghasilkan temuan yang tidak konsisten. Penelitian Nyamita et al. (2014); Sanusi dan Nazar (2014); dan menunjukkan bahwa pertumbuhan perusahaan memiliki pengaruh negatif terhadap kebijakan hutang. Namun penelitian Cortez dan Susanto (2012); Memon et al. (2015); Ramadhany et al. (2015) dan Firmansyah et al. (2016) menunjukkan bahwa pertumbuhan perusahaan berpengaruh positif terhadap kebijakan hutang.

Research gap juga terlihat pada pengaruh ukuran perusahaan terhadap kebijakan hutang. Penelitian yang dilakukan oleh; Nyamita et al. (2014); dan M'ng et al. (2017) menunjukkan bahwa ukuran perusahaan memiliki pengaruh negatif terhadap kebijakan hutang. Sedangkan Cortez dan Susanto (2012); Hidayat (2013); Memon et al. (2015); Firmansyah et al. (2016); dan M'ng et al. (2017) menunjukkan bahwa ukuran perusahaan berpengaruh positif terhadap kebijakan hutang. Ketidakkonsistenan hasil juga terdapat pada pengaruh antara blockholder ownership dengan kebijakan hutang. Penelitian yang dilakukan oleh Wiliandri (2011); serta Lestari (2014) menunjukkan bahwa blockholder ownership berpengaruh negatif terhadap kebijakan hutang. Sedangkan Maryasih dan Gemala (2014); serta Saputra et al. (2017); menunjukkan bahwa blockholder ownership berpengaruh positif terhadap kebijakan hutang.

Pengaruh tingkat inflasi terhadap kebijakan hutang didapatkan juga hasil yang tidak konsisten. Penelitian yang dilakukan oleh Firmansyah et al. (2016) dan M'ng et al. (2017) menunjukkan bahwa tingkat inflasi berpengaruh positif terhadap kebijakan hutang. Sedangkan Muthama et al. (2013) dan Nyamita et al. (2014) menunjukkan bahwa tingkat inflasi berpengaruh negatif terhadap kebijakan hutang.

Oleh sebab itu, peneliti membuat suatu penelitian dengan judul "Pengaruh Faktor Mikroekonomi dan Makroekonomi Perusahaan Terhadap Kebijakan Hutang (Studi Empiris pada Perusahaan Sektor Keuangan yang Terdaftar di Bursa Efek Indonesia Periode 2014 - 2018)”.

\section{B. LANDASAN TEORI DAN PENGEMBANGAN HIPOTESIS}

\section{Teori Keagenan}

Teori keagenan menjelaskan tentang hubungan keagenan yang timbul antara pemilik perusahaan (principal) dengan para manajer (agents). Teori keagenan membahas tentang keputusan pendanaan yang diambil oleh pihak manajemen (agent) apakah akan memberikan tambahan kekayaan bagi pemegang saham (principle) atau meningkatkan nilai perusahaan atau justru memberikan benefit lebih kepada manajemen atas adanya aliran kas bebas jika perusahaan memutuskan berhutang (Firmansyah et al., 2016).

\section{Teori Pecking Order}

Secara spesifik, perusahaan mempunyai urutan preferensi dalam penggunaan dana. Urutan dalam Pecking Order Theory adalah laba ditahan, hutang, dan penerbitan saham. Menurut teori pecking order, perusahaan yang mempunyai tingkat keuntungan yang tinggi justru mempunyai tingkat hutang yang lebih kecil tidak dikarenakan perusahaan mempunyai target tingkat hutang yang kecil, tetapi karena mereka tidak membutuhkan dana eksternal. Tingkat keuntungan yang tinggi menjadikan dana internal mereka cukup untuk memenuhi kebutuhan investasi.

\section{Kebijakan Hutang}

Menurut Firmansyah et al. (2016), kebijakan hutang adalah suatu keputusan pembiayaan yang dilakukan dengan berhutang kepada perbankan konvensional dalam jangka waktu tertentu, atau dapat juga dilakukan dengan perbankan ekspor impor dengan opsi membeli suatu produk pada negara tertentu dengan mendapatkan fasilitas kredit dari bank yang mengelola ekspor ataupun impor tersebut dan dapat juga 
menjual surat hutang berjangka berupa obligasi kepada pihak investor baik di dalam negeri ataupun diluar negeri dengan opsi tertentu untuk membiayai kegiatan operasional maupun investasinya.

\section{Faktor Mikroekonomi}

Menurut Brigham dan Houston (2011), perusahaan pada umumnya mempertimbangkan faktor-faktor mikroekonomi perusahaan ketika melakukan keputusan kebijakan hutang. Dalam penelitian ini digunakan variabel-variabel, yaitu pertumbuhan perusahaan, ukuran perusahaan, dan blockholder ownership.

\section{Pertumbuhan Perusahaan}

Pertumbuhan perusahaan merupakan gambaran perkembangan usaha yang dilakukan periode sekarang dibandingkan dengan periode sebelumnya (Saputra et al., 2017). Menurut Jong et al. (2007) dalam Firmansyah et al. (2016), perusahaan yang memiliki peluang bertumbuh yang baik dimasa yang akan datang akan tetap menjaga hutangnya tetap kecil, hal ini dikarenakan investor tidak menginginkan memindahkan kekayaannya ke kreditur. Berdasarkan teori agensi, semakin besar dan positif perubahan total pendapatan yang tinggi dapat meningkatkan laba perusahaan. Laba perusahaan yang tinggi menggambarkan kinerja perusahaan yang sudah baik, sehingga konflik agensi dapat diatasi dan tidak membutuhkan biaya pengawasan tambahan dari pihak kreditur.

Berdasarkan teori pecking order, semakin besar dan positif perubahan total pendapatan yang tinggi dapat menghasilkan laba yang besar. Sehingga, perusahaan akan memilih untuk menggunakan laba internal perusahaan untuk membiayai perusahaan. Pertumbuhan perusahaaan memiliki pengaruh negatif terhadap kebijakan hutang perusahaan terutama karena perusahaan lebih menggunakan laba internal (Sanusi dan Nazar, 2014). Pernyataan ini sejalan dengan penelitian yang dilakukan oleh Nyamita et al. (2014) mengatakan bahwa terdapat pengaruh antara pertumbuhan perusahaan terhadap kebijakan utang perusahaan. Berdasarkan uraian diatas dapat dirumuskan hipotesis sebagai berikut:

\section{H1: Pertumbuhan perusahaan berpengaruh negatif terhadap kebijakan hutang.}

\section{Ukuran Perusahaan}

Ukuran perusahaan adalah besar atau kecilnya suatu perusahaan (Sanjaya, 2014). Menurut Ifada dan Yunandriatna (2017), ukuran perusahaan merupakan keseluruhan aset yang dimiliki perusahaan. Semakin besar perusahaan dapat memberikan kemudahan akses pencarian dana dari sumber hutang karena perusahaan mempunyai collateral assets. Dengan demikian, semakin besar ukuran perusahaan, maka semakin besar kesanggupan perusahaan dalam mendapatkan keuntungan, dan semakin banyak kebutuhan akan modalnya yang berasal dari dana eksternal.Berdasarkan teori agensi, semakin besar total aset yang dibiayai melalui hutang dapat semakin memperkecil konflik antara manajer dan pemilik perusahaan, karena biaya pengawasan terhadap kinerja perusahaan akan dilakukan oleh pihak kreditur semakin besar. Bertambahnya aset perusahaan melalui hutang dapat meningkatkan kinerja perusahaan dan nilai perusahaan, serta menambah kekayaan pemilik perusahaan.

Berdasarkan teori pecking order, semakin besar total aset, maka semakin besar pula biaya yang ditanggung perusahaan, meliputi biaya pemeliharaan dan biaya penyusutan. Jika penggunaan laba ditahan untuk mencukupi biaya-biaya tersebut terbatas, sehingga alternatif pendanaan berikutnya adalah melalui hutang. Hasil penelitian yang ditemukan oleh Memon et al. (2015) menunjukkan bahwa terdapat pengaruh positif antara ukuran perusahaan dengan kebijakan hutang. Hasil yang sama ditemukan oleh Ifada dan Yunandriatna (2017); dan M'ng et al. (2017) menunjukkan bahwa ukuran perusahaan memiliki pengaruh positif terhadap kebijakan hutang.Berdasarkan uraian diatas dapat dirumuskan hipotesis sebagai berikut:

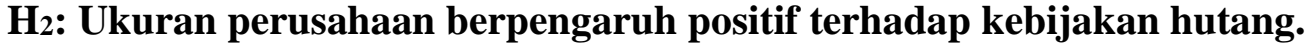

\section{Blockholder Ownership}

Menurut Dictio (2019), blockholder ownership merupakan kepemilikan saham suatu perusahaan dalam jumlah yang besar, dimana pemilik saham seringkali dapat memengaruhi kebijakan perusahaan yang didapat dari besarnya saham yang dimiliki. Menurut Undang-Undang Nomor 8 Tahun 1995 tentang Pasar 
Modal, Peraturan Otoritas Jasa Keuangan No. 9/POJK.04/2018 tentang Pengambilalihan Perusahaan Terbuka, Pasal 1, angka 4, dan Keputusan Direksi PT Bursa Efek Indonesia No. Kep-00059/BEI/07-2019, Pemegang Saham Utama adalah Pihak yang, baik secara langsung maupun tidak langsung, memiliki paling sedikit 20\% (dua puluh persen) hak suara dari seluruh saham yang mempunyai hak suara yang dikeluarkan oleh suatu perusahaan atau jumlah yang lebih kecil dari itu sebagaimana ditetapkan oleh Otoritas Jasa Keuangan. Hak suara yang lebih besar ini dapat digunakan dalam penentuan kebijakan yang akan diterapkan perusahaan, termasuk kebijakan hutang.

Menurut Maryasih dan Gemala (2014) dan Wiliandri (2011), semakin besar dan memusat penguasaan saham oleh sekelompok pemegang saham akan mendorong perusahaan lebih berani mengambil pinjaman sehingga meningkatkan DER. Berdasarkan teori agensi, semakin besar dan memusat blockholder ownership semakin besar pula penggunaan hutang karena hutang dapat digunakan untuk mengawasi manajer agar bertindak sesuai tujuan perusahaan, mengatasi konflik agensi yang terjadi antara pemegang saham mayoritas dan minoritas, dan dapat memberikan pendapatan atas saham dan laba perusahaan yang semakin tinggi karena adanya kebijakan perlindungan pajak atas bunga pinjaman, sehingga dapat mengurangi konflik agensi karena baik principal dan agent bersama-sama mendapatkan keuntungan dari hutang. Berdasarkan uraian diatas dapat dirumuskan hipotesis sebagai berikut:

\section{H3: Blockholder ownership berpengaruh positif terhadap kebijakan hutang.}

\section{Faktor Makroekonomi}

Menurut Khanna et al. (2018), faktor makroekonomi perusahaan memiliki pengaruh yang signifikan untuk kebijakan hutang perusahaan baik jangka pendek maupun jangka panjang. Dalam penelitian ini variabel-variabel yang digunakan adalah kestabilan politik dan tingkat inflasi.

\section{Kestabilan Politik}

Kestabilan politik adalah standar untuk mengukur persepsi tentang kemungkinan ketidakstabilan politik dan atau kekerasan bermotif politik, termasuk terorisme (Razak dan Suhadak, 2019). Ketidakstabilan politik akan mengarah pada kebijakan makroekonomi jangka pendek yang tidak optimal atau meningkatkan kebijakan yang tidak pasti, sehingga menghasilkan lingkungan politik-ekonomi yang tidak pasti, meningkatkan risiko bisnis, dan mengurangi investasi (Aisen dan Veiga, 2011). Ketidakstabilan politik akan mengarah pada kebijakan makroekonomi jangka pendek yang tidak optimal atau meningkatkan kebijakan yang tidak pasti, sehingga menghasilkan lingkungan politik-ekonomi yang tidak pasti, meningkatkan risiko bisnis, dan mengurangi investasi (Aisen dan Veiga, 2011).

Berdasarkan teori pecking order, ketika kestabilan politik naik, risiko politik akan turun, akan mengakibatkan meningkatnya perekonomian negara tersebut (Razak dan Suhadak, 2019), sehingga dalam perekonomian yang meningkat tersebut jika laba ditahan tidak mencukup untuk membiayai kegiatan perusahaan, maka perusahaan akan akan beralih menggunakan hutang untuk menambah modal kegiatan usahanya. Berdasarkan uraian diatas dapat dirumuskan hipotesis sebagai berikut:

\section{H4: Kestabilan politik berpengaruh positif terhadap kebijakan hutang.}

\section{Tingkat Inflasi}

Menurut Bank Indonesia, secara sederhana tingkat inflasi diartikan sebagai kenaikan harga secara umum dan terus menerus dalam jangka waktu tertentu. Menurut Staikouras dan Wood (2003) dalam Kosmidou (2008), inflasi memiliki efek langsung terhadap beban-beban perusahaan sektor keuangan. Beban operasional yang meningkat dapat menurunkan laba perusahaan, sehingga perusahaan cenderung menggunakan hutang (Firmansyah et al., 2016). Menurut Mukhlis (2016), bagi perusahaan sektor keuangan terjadinya inflasi dapat mempengaruhi alokasi kredit yang diberikan kepada kreditur. Dengan semakin tingginya inflasi, maka dalam perspektif produsen hal tersebut dapat berarti terjadinya kenaikan output di pasar. Kenaikan tersebut jika diiringi dengan kenaikan pendapatan masyarakat, maka akan meningkatkan pendapatan perusahaan sektor keuangan. 
Berdasarkan teori pecking order, peningkatan tingkat inflasi akan mengakibatkan peningkatan biaya operasional perusahaan, tetap dilain hal peningkatan inflasi dapat meningkatkan kinerja perusahaan, yaitu pendapatan dapat meningkat, untuk lebih meningkatkan kinerja perusahaan sektor keuangan ini dan menutupi biaya operasional perusahaan, perusahaan akan menambah modal dengan menggunakan hutang.

Hasil penelitian yang ditemukan oleh Firmansyah et al. (2016) menunjukkan bahwa terdapat pengaruh positif antara tingkat inflasi dengan kebijakan hutang. Hasil yang sama ditemukan oleh M'ng et al. (2017) menunjukkan bahwa tingkat inflasi memiliki pengaruh positif terhadap kebijakan hutangBerdasarkan uraian diatas dapat dirumuskan hipotesis sebagai berikut:

\section{H5: Tingkat inflasi berpengaruh positif terhadap kebijakan hutang.}

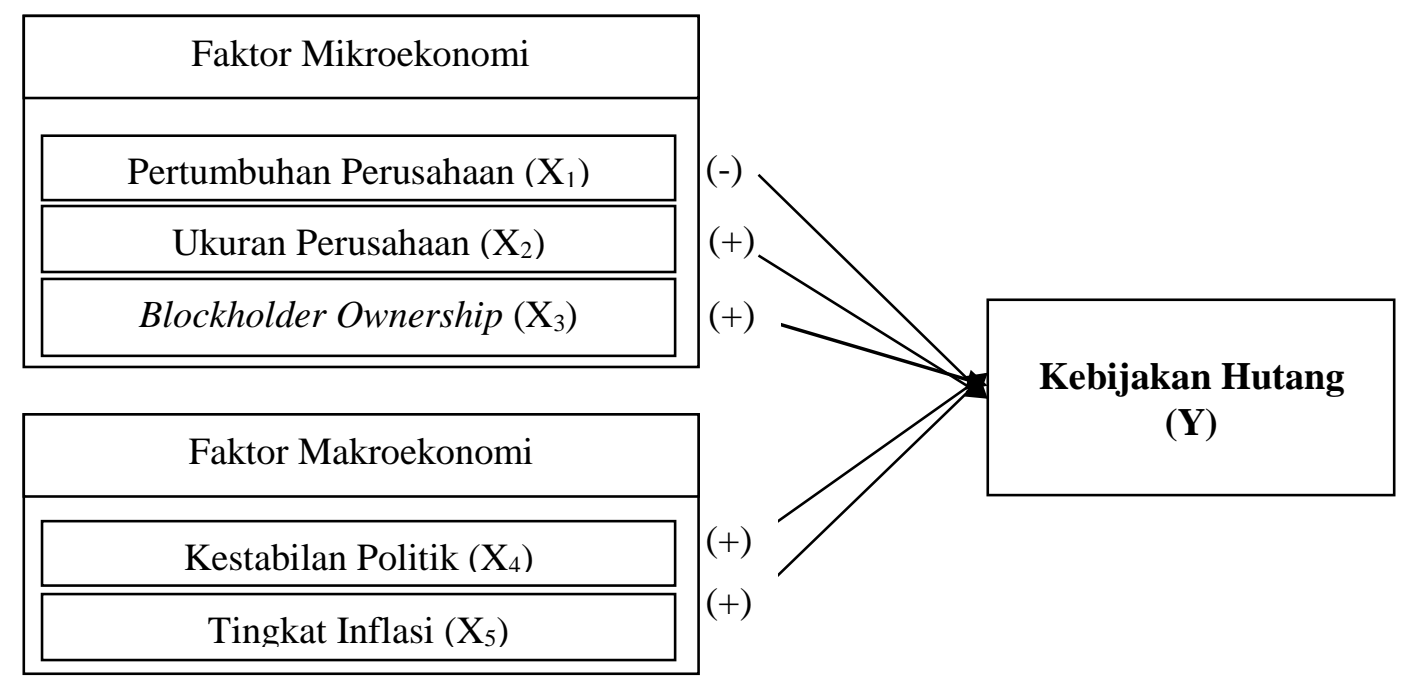

Gambar 2 Kerangka Pemikiran

\section{METODE PENELITIAN}

\section{Teori Keagenan}

Teori keagenan menjelaskan tentang hubungan keagenan yang timbul antara pemilik perusahaan (principal) dengan para manajer (agents). Teori keagenan membahas tentang keputusan pendanaan yang diambil oleh pihak manajemen (agent) apakah akan memberikan tambahan kekayaan bagi pemegang saham (principle) atau meningkatkan nilai perusahaan atau justru memberikan benefit lebih kepada manajemen atas adanya aliran kas bebas jika perusahaan memutuskan berhutang (Firmansyah et al., 2016).

\section{Teori Pecking Order}

Secara spesifik, perusahaan mempunyai urutan preferensi dalam penggunaan dana. Urutan dalam Pecking Order Theory adalah laba ditahan, hutang, dan penerbitan saham. Menurut teori pecking order, perusahaan yang mempunyai tingkat keuntungan yang tinggi justru mempunyai tingkat hutang yang lebih kecil tidak dikarenakan perusahaan mempunyai target tingkat hutang yang kecil, tetapi karena mereka tidak membutuhkan dana eksternal. Tingkat keuntungan yang tinggi menjadikan dana internal mereka cukup untuk memenuhi kebutuhan investasi.

\section{Kebijakan Hutang}

Menurut Firmansyah et al. (2016), kebijakan hutang adalah suatu keputusan pembiayaan yang dilakukan dengan berhutang kepada perbankan konvensional dalam jangka waktu tertentu, atau dapat juga dilakukan dengan perbankan ekspor impor dengan opsi membeli suatu produk pada negara tertentu dengan mendapatkan fasilitas kredit dari bank yang mengelola ekspor ataupun impor tersebut dan dapat juga menjual surat hutang berjangka berupa obligasi kepada pihak investor baik di dalam negeri ataupun diluar negeri dengan opsi tertentu untuk membiayai kegiatan operasional maupun investasinya. 


\section{Faktor Mikroekonomi}

Menurut Brigham dan Houston (2011), perusahaan pada umumnya mempertimbangkan faktor-faktor mikroekonomi perusahaan ketika melakukan keputusan kebijakan hutang. Dalam penelitian ini digunakan variabel-variabel, yaitu pertumbuhan perusahaan, ukuran perusahaan, dan blockholder ownership.

\section{Pertumbuhan Perusahaan}

Pertumbuhan perusahaan merupakan gambaran perkembangan usaha yang dilakukan periode sekarang dibandingkan dengan periode sebelumnya (Saputra et al., 2017). Menurut Jong et al. (2007) dalam Firmansyah et al. (2016), perusahaan yang memiliki peluang bertumbuh yang baik dimasa yang akan datang akan tetap menjaga hutangnya tetap kecil, hal ini dikarenakan investor tidak menginginkan memindahkan kekayaannya ke kreditur. Berdasarkan teori agensi, semakin besar dan positif perubahan total pendapatan yang tinggi dapat meningkatkan laba perusahaan. Laba perusahaan yang tinggi menggambarkan kinerja perusahaan yang sudah baik, sehingga konflik agensi dapat diatasi dan tidak membutuhkan biaya pengawasan tambahan dari pihak kreditur.

Berdasarkan teori pecking order, semakin besar dan positif perubahan total pendapatan yang tinggi dapat menghasilkan laba yang besar. Sehingga, perusahaan akan memilih untuk menggunakan laba internal perusahaan untuk membiayai perusahaan. Pertumbuhan perusahaaan memiliki pengaruh negatif terhadap kebijakan hutang perusahaan terutama karena perusahaan lebih menggunakan laba internal (Sanusi dan Nazar, 2014). Pernyataan ini sejalan dengan penelitian yang dilakukan oleh Nyamita et al. (2014) mengatakan bahwa terdapat pengaruh antara pertumbuhan perusahaan terhadap kebijakan utang perusahaan. Berdasarkan uraian diatas dapat dirumuskan hipotesis sebagai berikut:

$\mathrm{H}_{1}$ : Pertumbuhan perusahaan berpengaruh negatif terhadap kebijakan hutang.

\section{Ukuran Perusahaan}

Ukuran perusahaan adalah besar atau kecilnya suatu perusahaan (Sanjaya, 2014). Menurut Ifada dan Yunandriatna (2017), ukuran perusahaan merupakan keseluruhan aset yang dimiliki perusahaan. Semakin besar perusahaan dapat memberikan kemudahan akses pencarian dana dari sumber hutang karena perusahaan mempunyai collateral assets. Dengan demikian, semakin besar ukuran perusahaan, maka semakin besar kesanggupan perusahaan dalam mendapatkan keuntungan, dan semakin banyak kebutuhan akan modalnya yang berasal dari dana eksternal.

Berdasarkan teori agensi, semakin besar total aset yang dibiayai melalui hutang dapat semakin memperkecil konflik antara manajer dan pemilik perusahaan, karena biaya pengawasan terhadap kinerja perusahaan akan dilakukan oleh pihak kreditur semakin besar. Bertambahnya aset perusahaan melalui hutang dapat meningkatkan kinerja perusahaan dan nilai perusahaan, serta menambah kekayaan pemilik perusahaan.Berdasarkan teori pecking order, semakin besar total aset, maka semakin besar pula biaya yang ditanggung perusahaan, meliputi biaya pemeliharaan dan biaya penyusutan. Jika penggunaan laba ditahan untuk mencukupi biaya-biaya tersebut terbatas, sehingga alternatif pendanaan berikutnya adalah melalui hutang. Hasil penelitian yang ditemukan oleh Memon et al. (2015) menunjukkan bahwa terdapat pengaruh positif antara ukuran perusahaan dengan kebijakan hutang. Hasil yang sama ditemukan oleh Ifada dan Yunandriatna (2017); dan M'ng et al. (2017) menunjukkan bahwa ukuran perusahaan memiliki pengaruh positif terhadap kebijakan hutang.Berdasarkan uraian diatas dapat dirumuskan hipotesis sebagai berikut: $\mathrm{H}_{2}$ : Ukuran perusahaan berpengaruh positif terhadap kebijakan hutang.

\section{Blockholder Ownership}

Menurut Dictio (2019), blockholder ownership merupakan kepemilikan saham suatu perusahaan dalam jumlah yang besar, dimana pemilik saham seringkali dapat memengaruhi kebijakan perusahaan yang didapat dari besarnya saham yang dimiliki. Menurut Undang-Undang Nomor 8 Tahun 1995 tentang Pasar Modal, Peraturan Otoritas Jasa Keuangan No. 9/POJK.04/2018 tentang Pengambilalihan Perusahaan Terbuka, Pasal 1, angka 4, dan Keputusan Direksi PT Bursa Efek Indonesia No. Kep-00059/BEI/07-2019, 
Pemegang Saham Utama adalah Pihak yang, baik secara langsung maupun tidak langsung, memiliki paling sedikit 20\% (dua puluh persen) hak suara dari seluruh saham yang mempunyai hak suara yang dikeluarkan oleh suatu perusahaan atau jumlah yang lebih kecil dari itu sebagaimana ditetapkan oleh Otoritas Jasa Keuangan. Hak suara yang lebih besar ini dapat digunakan dalam penentuan kebijakan yang akan diterapkan perusahaan, termasuk kebijakan hutang.

Menurut Maryasih dan Gemala (2014) dan Wiliandri (2011), semakin besar dan memusat penguasaan saham oleh sekelompok pemegang saham akan mendorong perusahaan lebih berani mengambil pinjaman sehingga meningkatkan DER. Berdasarkan teori agensi, semakin besar dan memusat blockholder ownership semakin besar pula penggunaan hutang karena hutang dapat digunakan untuk mengawasi manajer agar bertindak sesuai tujuan perusahaan, mengatasi konflik agensi yang terjadi antara pemegang saham mayoritas dan minoritas, dan dapat memberikan pendapatan atas saham dan laba perusahaan yang semakin tinggi karena adanya kebijakan perlindungan pajak atas bunga pinjaman, sehingga dapat mengurangi konflik agensi karena baik principal dan agent bersama-sama mendapatkan keuntungan dari hutang. Berdasarkan uraian diatas dapat dirumuskan hipotesis sebagai berikut:

$\mathrm{H}_{3}$ : Blockholder ownership berpengaruh positif terhadap kebijakan hutang.

\section{Faktor Makroekonomi}

Menurut Khanna et al. (2018), faktor makroekonomi perusahaan memiliki pengaruh yang signifikan untuk kebijakan hutang perusahaan baik jangka pendek maupun jangka panjang. Dalam penelitian ini variabel-variabel yang digunakan adalah kestabilan politik dan tingkat inflasi.

\section{Kestabilan Politik}

Kestabilan politik adalah standar untuk mengukur persepsi tentang kemungkinan ketidakstabilan politik dan atau kekerasan bermotif politik, termasuk terorisme (Razak dan Suhadak, 2019). Ketidakstabilan politik akan mengarah pada kebijakan makroekonomi jangka pendek yang tidak optimal atau meningkatkan kebijakan yang tidak pasti, sehingga menghasilkan lingkungan politik-ekonomi yang tidak pasti, meningkatkan risiko bisnis, dan mengurangi investasi (Aisen dan Veiga, 2011).

Ketidakstabilan politik akan mengarah pada kebijakan makroekonomi jangka pendek yang tidak optimal atau meningkatkan kebijakan yang tidak pasti, sehingga menghasilkan lingkungan politik-ekonomi yang tidak pasti, meningkatkan risiko bisnis, dan mengurangi investasi (Aisen dan Veiga, 2011).

Berdasarkan teori pecking order, ketika kestabilan politik naik, risiko politik akan turun, akan mengakibatkan meningkatnya perekonomian negara tersebut (Razak dan Suhadak, 2019), sehingga dalam perekonomian yang meningkat tersebut jika laba ditahan tidak mencukup untuk membiayai kegiatan perusahaan, maka perusahaan akan akan beralih menggunakan hutang untuk menambah modal kegiatan usahanya. Berdasarkan uraian diatas dapat dirumuskan hipotesis sebagai berikut:

$\mathrm{H}_{4}$ : Kestabilan politik berpengaruh positif terhadap kebijakan hutang.

\section{Tingkat Inflasi}

Menurut Bank Indonesia, secara sederhana tingkat inflasi diartikan sebagai kenaikan harga secara umum dan terus menerus dalam jangka waktu tertentu. Menurut Staikouras dan Wood (2003) dalam Kosmidou (2008), inflasi memiliki efek langsung terhadap beban-beban perusahaan sektor keuangan. Beban operasional yang meningkat dapat menurunkan laba perusahaan, sehingga perusahaan cenderung menggunakan hutang (Firmansyah et al., 2016).

Menurut Mukhlis (2016), bagi perusahaan sektor keuangan terjadinya inflasi dapat mempengaruhi alokasi kredit yang diberikan kepada kreditur. Dengan semakin tingginya inflasi, maka dalam perspektif produsen hal tersebut dapat berarti terjadinya kenaikan output di pasar. Kenaikan tersebut jika diiringi dengan kenaikan pendapatan masyarakat, maka akan meningkatkan pendapatan perusahaan sektor keuangan.

Berdasarkan teori pecking order, peningkatan tingkat inflasi akan mengakibatkan peningkatan biaya 
operasional perusahaan, tetap dilain hal peningkatan inflasi dapat meningkatkan kinerja perusahaan, yaitu pendapatan dapat meningkat, untuk lebih meningkatkan kinerja perusahaan sektor keuangan ini dan menutupi biaya operasional perusahaan, perusahaan akan menambah modal dengan menggunakan hutang.

Hasil penelitian yang ditemukan oleh Firmansyah et al. (2016) menunjukkan bahwa terdapat pengaruh positif antara tingkat inflasi dengan kebijakan hutang. Hasil yang sama ditemukan oleh M'ng et al. (2017) menunjukkan bahwa tingkat inflasi memiliki pengaruh positif terhadap kebijakan hutangBerdasarkan uraian diatas dapat dirumuskan hipotesis sebagai berikut:

$\mathrm{H}_{5}$ : Tingkat inflasi berpengaruh positif terhadap kebijakan hutang.

\section{ANALISIS DAN PEMBAHASAN}

\section{Analisis Regresi Berganda}

Tabel 1 Hasil Analisis Regresi Berganda

\begin{tabular}{lcc}
\hline \multicolumn{1}{c}{ Variabel } & B & Sig. \\
\hline \hline Konstanta & $-2,407$ & 0,000 \\
SQRT_GROWTH & $-0,252$ & 0,002 \\
SQRT_SIZE & 0,651 & 0,000 \\
SQRT_BO & 0,725 & 0,008 \\
SQRT_PS & 0,050 & 0,863 \\
SQRT_INFL & 0,142 & 0,222 \\
\hline \hline
\end{tabular}

Sumber : Data Olahan SPSS 23

Berdasarkan Tabel 1, maka model regresi yang didapat ialah:

\section{DER = -2,407 - 0,252GROWTH + 0,651SIZE + 0,725BO + 0,050PS + 0,142INFL}

Keterangan :

$\begin{array}{ll}\text { DER } & =\text { Kebijakan Hutang } \\ \text { GROWTH } & =\text { Pertumbuhan Perusahaan } \\ \text { SIZE } & =\text { Ukuran Perusahaan } \\ \text { BO } & =\text { Blockholder Ownership } \\ \text { PS } & =\text { Kestabilan Politik } \\ \text { INFL } & =\text { Tingkat Inflasi }\end{array}$

Berdasarkan Tabel 4.1, dengan tingkat siginfikansi 0,05, variabel GROWTH memiliki nilai signifikan sebesar 0,002 < nilai signifikansi 0,05, maka dapat disimpulkan bahwa $\mathrm{H}_{1}$ atau hipotesis pertama diterima. Variabel SIZE memiliki nilai signifikan sebesar $0,000<$ nilai signifikansi 0,05 , maka dapat disimpulkan bahwa $\mathrm{H}_{2}$ atau hipotesis kedua diterima. Variabel BO memiliki nilai signifikan sebesar 0,008 < nilai signifikansi 0,05 maka dapat disimpulkan bahwa $\mathrm{H}_{3}$ atau hipotesis ketiga diterima. Variabel PS memiliki nilai signifikan sebesar 0,873 > nilai signifikansi 0,05, maka dapat disimpulkan bahwa $\mathrm{H}_{4}$ atau hipotesis keempat ditolak. Variabel INFL memiliki nilai signifikan sebesar 0,222 > nilai signifikansi 0,05, maka dapat disimpulkan bahwa $\mathrm{H}_{5}$ atau hipotesis kelima ditolak.

\section{Uji Koefisien Determinasi $\mathbf{R}^{2}$}

Tabel 2 Hasil Uji Koefisien Determinasi R ${ }^{2}$

Model Summary

\begin{tabular}{|l|l|l|r|r|}
\hline Model & $\mathrm{R}$ & R Square & $\begin{array}{c}\text { Adjusted R } \\
\text { Square }\end{array}$ & $\begin{array}{c}\text { Std. Error of } \\
\text { the Estimate }\end{array}$ \\
\hline 1 &, $571^{\mathrm{a}}$ &, 327 &, 305 &, 6235365 \\
\hline
\end{tabular}

Sumber : Data Olahan SPSS 23 
Berdasarkan Tabel 4.2, nilai adjusted R Square adalah sebesar 0,327 yang menunjukkan bahwa proporsi pengaruh variabel Pertumbuhan Perusahaan (GROWTH), Ukuran Perusahaan (SIZE), Blockholder Ownership (BO), Kestabilan Politik (PS), dan Tingkat Inflasi (INFL) terhadap variabel Kebijakan Hutang (DER) sebesar 32,7\%, sedangkan sisanya 67,3\% dipengaruhi oleh faktor lain yang tidak ada dalam model regresi.

\section{PEMBAHASAN}

\section{Pengaruh Pertumbuhan Perusahaan Terhadap Kebijakan Hutang}

Hasil penelitian ini mendukung penelitian yang dilakukan oleh Nyamita et al. (2014), Sanusi dan Nazar (2014), dan Ramadhany et al. (2015). Semakin tinggi pendapatan yang mampu dihasilkan maka semakin besar laba perusahaan, sehingga perusahaan akan lebih mengandalkan laba internal (Sanusi dan Nazar, 2014). Hal ini mendukung teori agensi, yaitu semakin besar dan positif perubahan total pendapatan dapat meningkatkan laba perusahaan. Laba perusahaan yang tinggi menggambarkan kinerja perusahaan yang baik, sehingga konflik agensi dapat diatas dan tidak membutuhkan biaya pengawasan tambahan dari pihak kreditur.

\section{Pengaruh Ukuran Perusahaan Terhadap Kebijakan Hutang}

Hasil penelitian ini mendukung penelitian yang dilakukan oleh Memon et al. (2015) dan M'ng et al. (2017). Menurut Ifada dan Yunandriatna (2014), semakin besar ukuran perusahaan dapat memberikan kemudahan akses pencairan dana dari sumber hutang karena perusahaan mempunyai collateral assets. Hal ini juga mendukung teori pecking order, yaitu semakin besar total aset, maka semakin besar pula biaya yang ditanggung perusahaan, meliputi biaya pemeliharaan dan biaya penyusutan. Jika penggunaan laba ditahan untuk mencukupi biaya-biaya tersebut terbatas, maka alternatif pendanaan berikutnya adalah melalui hutang.

\section{Pengaruh Blockholder Ownership Terhadap Kebijakan Hutang}

Hasil penelitian ini mendukung penelitian yang dilakukan oleh Maryasih dan Gemala (2014), serta Saputra et al. (2017). Menurut Maryasih dan Gemala (2014) dan Wiliandri (2011), semakin besar dan memusat penguasaan saham oleh sekelompok pemegang saham akan mendorong perusahaan lebih berani mengambil pinjaman sehingga meningkatkan DER karena dalam mengambil berbagai keputusan perusahaan blockholder memiliki kekuasaan yang lebih, termasuk kebijakan hutang.

\section{Pengaruh Kestabilan Politik Terhadap Kebijakan Hutang}

Ketika kestabilan politik naik, risiko politik akan turun, akan mengakibatkan meningkatnya perekonomian negara tersebut (Razak dan Suhadak, 2019), sehingga dalam perekonomian yang meningkat tersebut jika laba ditahan tidak mencukup untuk membiayai kegiatan perusahaan, maka perusahaan akan akan beralih menggunakan hutang untuk menambah modal kegiatan usahanya. Berdasarkan Tabel 3, pada tahun 2016 perubahan beban perusahaan sektor keuangan lebih besar daripada perubahan pendapatannya, sehingga perusahaan cenderung menurunkan penggunaan hutangnya. Pada tahun 2014-2018, penanaman modal asing terus meningkat. Perusahaan dapat mengandalkan penanaman modal investasi yang diperoleh.

Tabel 3 Pendapatan, Beban Perusahaan Sektor Keuangan, dan Penanaman

Modal Invetasi tahun 2014-2018 (dalam triliun Rupiah)

\begin{tabular}{|c|c|c|c|c|c|}
\hline & 2014 & 2015 & 2016 & 2017 & 2018 \\
\hline Pendapatan sektor keuangan & Rp319,8 & Rp347,1 & Rp378,3 & Rp398,9 & Rp415,6 \\
\hline Perubahan $(\%)$ & - & $8,54 \%$ & $8,99 \%$ & $5,45 \%$ & $4,19 \%$ \\
\hline Beban-beban sektor keuangan & $\operatorname{Rp} 234,1$ & $\operatorname{Rp} 250,3$ & Rp280 & Rp276,5 & $\operatorname{Rp} 276,4$ \\
\hline Perubahan $(\%)$ & - & $6,89 \%$ & $12,29 \%$ & $-1,62 \%$ & $-0,05 \%$ \\
\hline Penanaman modal investasi & Rp463,7 & Rp545,4 & Rp612,8 & Rp692,8 & Rp721,3 \\
\hline
\end{tabular}

Sumber : BPS, BKPM, dan Laporan Keuangan, data diolah. 


\section{Pengaruh Tingkat Inflasi Terhadap Kebijakan Hutang}

Hasil penelitian ini mendukung penelitian yang dilakukan oleh Firmansyah et al. (2016), serta M'ng et al. (2017). Sebaliknya, menurut Mukhlis (2016), semakin tinggi inflasi, kenaikan output akan semakin, jika tidak diimbangi dengan kenaikan pendapatan masyarakat untuk membayar pinjaman akan mengakibatkan kredit macet, sehingga menurunkan kinerja perusahaan sektor keuangan dan menambah beban perusahaan. Pada saat titik tertentu dimana beban perusahaan lebih besar daripada pendapatannya, perusahaan akan mengurangi jumlah hutang yang digunakan untuk menurunkan beban bunganya. Hal ini diperlihatkan dalam Tabel 4, pada tahun 2016 perubahan beban perusahaan sektor keuangan lebih besar daripada perubahan pendapatannya, sehingga perusahaan cenderung menurunkan penggunaan hutangnya.

Tabel 4 Pendapatan dan Beban Perusahaan Sektor Keuangan 2014-2018

(dalam triliun Rupiah)

\begin{tabular}{lccccc}
\hline & $\mathbf{2 0 1 4}$ & $\mathbf{2 0 1 5}$ & $\mathbf{2 0 1 6}$ & $\mathbf{2 0 1 7}$ & $\mathbf{2 0 1 8}$ \\
\hline \hline Pendapatan sektor keuangan & Rp319,8 & Rp347,1 & Rp378,3 & Rp398,9 & Rp415,6 \\
Perubahan (\%) & - & $8,54 \%$ & $8,99 \%$ & $5,45 \%$ & $4,19 \%$ \\
Beban-beban sektor keuangan & Rp234,1 & Rp250,3 & Rp280 & Rp276,5 & Rp276,4 \\
Perubahan (\%) & - & $6,89 \%$ & $12,29 \%$ & $-1,62 \%$ & $-0,05 \%$ \\
\hline \hline
\end{tabular}

Sumber : BPS dan Laporan Keuangan, data diolah.

\section{E. SIMPULAN DAN SARAN}

\section{Kesimpulan}

1. Pertumbuhan perusahaan berpengaruh negatif signifikan terhadap kebijakan hutang pada perusahaan sektor keuangan yang terdaftar di Bursa Efek Indonesia tahun 2014-2018 yang dibuktikan melalui pengujian signifikansi dengan hasil nilai signifikansi 0,002 atau lebih kecil dari 0,05.

2. Ukuran perusahaan berpengaruh positif signifikan terhadap kebijakan hutang pada perusahaan sektor keuangan yang terdaftar di Bursa Efek Indonesia tahun 2014-2018 yang dibuktikan melalui pengujian signifikansi dengan hasil nilai signifikansi 0,000 atau lebih kecil dari 0,05.

3. Blockholder ownership berpengaruh positif signifikan terhadap kebijakan hutang pada perusahaan sektor keuangan yang terdaftar di Bursa Efek Indonesia tahun 2014-2018 yang dibuktikan melalui pengujian signifikansi dengan hasil nilai signifikansi 0,008 atau lebih besar dari 0,05.

4. Kestabilan politik tidak berpengaruh signifikan terhadap kebijakan hutang pada perusahaan sektor keuangan yang terdaftar di Bursa Efek Indonesia tahun 2014-2018 yang dibuktikan melalui pengujian signifikansi dengan hasil nilai signifikansi 0,863 atau lebih besar dari 0,05.

5. Tingkat inflasi tidak berpengaruh signifikan terhadap kebijakan hutang pada perusahaan sektor keuangan yang terdaftar di Bursa Efek Indonesia tahun 2014-2018 yang dibuktikan melalui pengujian signifikansi dengan hasil nilai signifikansi 0,222 atau lebih besar dari 0,05.

\section{Saran}

1. Peneliti selanjutnya diharapkan dapat menambah faktor mikroekonomi lain seperti kepemilikan asing, kepemilikan publik, dan corporate governance dalam penelitiannya agar dapat meberikan hasil yang lebih baik dalam menggambarkan faktor mikroekonomi perusahaan.

2. Peneliti selanjutnya diharapkan dapat menambah faktor makroekonomi lain seperti cadangan devisa, PDB, IHSG, dan lain-lain dalam penelitiannya agar dapat meberikan hasil yang lebih baik dalam menggambarkan faktor makroekonomi perusahaan.

\section{REFERENSI}

Aisen, A., dan Veiga, F. J. 2011. How Does Political Instability Affect Economic Growth?. IMF Working Paper. WP/11/12.

Brigham, Eugene F., dan Houston, Joel F. 2011. Dasar-dasar Manajemen Keuangan. Edisi 11, Buku 2. Jakarta: Salemba Empat.

Bank Indonesia. 2019. Surat Utang Luar Negeri Indonesia. Jakarta: Bank Indonesia. 
Darsono. 2001. Corporate Governance: State of the America. Jurnal Bisnis Strategi. Vol. 7.

Dictio. 2019. “Apa yang Dimaksud dengan Blockholder Ownership?”. https://www.dictio.id/t/apa-yang-dimaksuddengan-blockholder-ownership/120685. (Diakses tanggal 10 Oktober 2019).

Fahmi, Irfan. 2014. Manajemen Keuangan Perusahaan dan Pasar Modal. Jakarta: Mitra Wacana Media.

Firmansyah, R. Y., Sudarma, M., dan Widia, Y. P. 2016. Faktor Internal dan Eksternal yang Berpengaruh terhadap Kebijakan Hutang dan Nilai Perusahaan. Jurnal Balance. Vol. XVIII, No. 1.

Gumiwang, Ringkang. 2018. "Mengapa Perusahaan Terbelit Utang Hingga Berakhir Pailit?". http://tirto.id/mengapa-perusahaan-terbelit-utang-hingga-berakhir-pailit-cEow. (diakses tanggal 12 Agustus 2019).

Hanafi, Mamduh M. 2016. Manajemen Keuangan. Edisi Kedua. Yogyakarta: BPFE-Yogyakarta.

Hidayat, M. S. 2013. Pengaruh Kepemilikan Manajerial, Kebijakan Dividen, Strukur Aktiva, Pertumbuhan Penjualan, dan Ukuran Perusahaan terhadap Kebijakan Utang. Jurnal Ilmu Manajemen. Vol. 1, No. 1.

Ifada, Luluk M., dan Yunandriatma. Faktor-faktor yang Berpengaruh terhadap Kebijakan Hutang Perusahaan. Jurnal Akuntansi dan Audit. Vol. 14, No. 1.

Khanna, Sakshi., Srivastava, Amit., dan Medury, Yajulu. 2015. The Effect of Macroeconomic Variables on the Capital Structure Decisions of Indian Firms: A Vector Error Correction Model/Vector Autoregressive Approach. International Journal of Economics and Financial Issues. Vol. 5, Issue 4.

Kosmidou, Kyriaki. 2008. The determinants of banks' profit in Greece during the period of EU financial integration. Managerial Finance Journal. Vol. 34. No. 3.

Lestari, Desi. 2014. Pengaruh Blockholder Ownership, Ukuran Perusahaan, Risiko Bisnis, Dan Nondebt Tax Shield Terhadap Kebijakan Hutang Perusahaan Yang Masuk Di Jakarta Islamic Index. Jurnal Ekonomi dan Bisnis Islam. Vol. IX. No. 1.

M'ng, J. C. P., Rahman M., dan Sannacy S. 2017. The Determinants of Capital Structure: Evidence from Public Listed Companies in Malaysia, Singapore, and Thailand. Cogent Economics and Finance. Vol. 5.

Maryasih, L., dan Gemala, M. Z. 2014. Analisis Pengaruh Blockholder Ownership dan Asset Tangibility terhadap Kebijakan Hutang pada Perusahaan Telekomunikasi yang Terdaftar di BEI Periode 2008-2011. Jurnal Dinamika Akuntansi dan Bisnis. Vol. 1. No. 1.

Memon, P. A., Rus R. B. M., dan Ghazali Z. B. 2015. Firm and Macroeconomic Determinants of Debt: Pakistan Evidence. Procedia-Social and Behavioral Science. Volume 172.

Mukhlis, Imam. 2012. Kinerja Keuangan Bank dan Stabilitas Makroekonomi Terhadap Profitabilitas Bank Syariah di Indonesia. Jurnal Keuangan dan Perbankan. Vol. 16. No. 2.

Nyamita, M. O., Garbharran, H. L., dan Dorasamy N. 2014. Factors Influencing Debt Financing within State-owned Corporations in Kenya. Journal of Economics and Behavioral Studies. Vol. 6, No. 11.

Ramadhany, R., Aminah, M., dan Permanasari, Y. 2015. Analisis Faktor yang Mempengaruhi Kebijakan Hutang Emiten Pertanian di Bursa Efek Indonesia. Jurnal Manajemen dan Organisasi. Vol. VI, No. 3.

Razak, A.M., dan Suhadak. 2019. Pengaruh Worldwide Governance Indicators dan Macroeconomic Terhadap IHSG. Jurnal Administrasi Bisnis. Vol. 70 No. 1.

Sanjaya, R., 2014. Variabel-variabel yang Mempengaruhi Kebijakan Hutang. Jurnal Bisnis dan Akuntansi. Vol. 16, No. 1.

Sanusi, S. W., dan Nazar, M. R. 2014. Analisis Pertumbuhan Perusahaan, Profitabilitas, dan Dividen Terhadap Kebijakan Hutang Perusahaan.

Jurnal Keuangan dan Bisnis. Vol. 12. No. 2.

Saputra, Doni H., Munthe, Inge L. S., dan Sofia, Myrna. 2017. Pengaruh Cash Flow, Kebijakan Dividen, Struktur Aktiva, Blockholder Ownership, Pertumbuhan Perusahaan terhadap Kebijakan Hutang pada Perusahaan Manufaktur yang Terdaftar di Bursa Efek Indonesia Periode 2011-2015. Jurnal Ilmiah Akuntansi. Vol. 1.

Soraya, dan Permanasari, M. 2017. Faktor-faktor yang Berpengaruh terhadap Kebijakan Hutang Perusahaan Non Keuangan Publik. Jurnal Akuntansi dan Audit. Vol. 19, No. 1.

Wiliandri, Ruly. 2011. Pengaruh Blockholder Ownership dan Firm Size terhadap Kebijakan Hutang Perusahaan. Jurnal Ekonomi Bisnis. No. 2.

Web www.bi.go.id

Web www.bkpm.go.id

Web www.bps.go.id

Web idx.co.id

Web www.info.worldbank/governance/wgi 